Research Article

Araştırma Makalesi

DOI: $10.24011 /$ barofd.773189
Bartın Orman Fakultesi Dergisi, 22 (3): 791-801,

15 Aralı//December, 2020
Journal of Bartin Faculty of Forestry

p-ISSN :1302-0943

e-ISSN :1308-5875

\title{
Salgının Öğretileri ve Yeni Dış Mekân Kullanımları
}

\author{
Cansu DİNÇTÜRK, İdil DAL, Sebahat AÇIKSÖZ \\ Bartın Üniversitesi, Mühendislik ve Mimarlık Fakültesi, Peyzaj Mimarlığı Bölümü, 74100, Bartın
}

Öz

2019 yılının sonlarına doğru Çin'in Wuhan kentinde ortaya çıkan bir virüs olan COVID-19 virüsü, Dünya Sağlık Örgütü (DSÖ)'ne bildirilmiş, hızla yayılmaya başlaması sebebiyle küresel ölçekte pandemi ilan edilmiştir. COVID-19 her yaştan insanı enfekte etmekte, bazı grupları daha fazla etkilemektedir. Salgının yayılmasına etki etmeye çalışan ülkeler etkinlikleri iptal etmek, sokağa çıkma yasağı uygulamak veya dış mekânların kullanımını kısıtlamak gibi önlemler almaktadır. Virüsün kentsel mekândaki yayılma hızının azaltılmasında kentteki sosyal mesafenin artırılmasının rolü büyüktür. Bu bağlamda hâlihazırdaki kentsel sistemlerin güçlendirilmesi gerekmektedir. Bu çalışma, insan-çevre-salgın ilişkisi üzerinden ekolojik temelli, sürdürülebilir ve sağlıklı kentler yaratılmasında, çevre ve toplum sağlığının gözetilmesini amaçlamaktadır. Çalışmada insan, çevre ve salgın konularına ilişkin genel ve mekânsal algının değerlendirilebilmesi için anket çalışması yapılmış ve elde edilen veriler SPSS 23.0 programında değerlendirilmiștir. Öncelikle demografik veriler daha sonra, insan, peyzaj ve salgın arasındaki ilişkinin ölçülmesine yönelik önermeler değerlendirilmiş; sonuç olarak "Pandemi faktörünün peyzaja etkilerine ilişkin tespitlerde" bulunulmuştur. Araştırmada kamusal alandaki yaşam koşullarının iyileştirilmesi adına; yeni dış mekân kullanımlarına, toplum sağlığının iyileştirilmesine ve yetkili kurumlara yönelik öneriler sunulmuştur.

Anahtar Kelimeler: COVID-19, salgın, dış mekân kullanımları, peyzaj yönetimi.

\section{Doctrines of the Pandemic and New Outdoor Uses}

\begin{abstract}
A virus (COVID-19) that emerged in Wuhan, China towards the end of 2019 was reported to the World Health Organization (WHO) and was declared as a pandemic on a global scale as it began to spread rapidly. The COVID19 virus can be transmitted to people of all ages, but it affects some groups more. Countries trying to influence the pace of the pandemic take measures such as canceling events, imposing curfews or restricting the use of outdoor spaces. Increasing the social distance in the city plays a major role in reducing the spread of the virus in urban space. In this context, existing urban systems need to be strengthened. This study aims to protect the environment and community health in creating sustainable and healthy cities based on human-environment-epidemic. In order to evaluate the general and spatial perception of human, environment and epidemic issues in the study, a survey study was conducted, and the data obtained were evaluated in the SPSS 23.0 program. Firstly, demographic data and then propositions for measuring the relationship between human-landscape-epidemic were evaluated; as a result, "determinations regarding the effects of the pandemic factor on the landscape" were made. To improve the living conditions in the public sphere; suggestions for outdoor use, improvement of public health and competent institutions were presented.
\end{abstract}

Keywords: COVID-19, pandemic, outdoor uses, landscape management. 


\section{Giriş}

Bir bireyin veya toplulukların yaşamlarını etkileyen sosyal ve kültürel koşulları sürdürdükleri canlı ve cansız ortam, çevre olarak tanımlanmaktadır. Yeryüzündeki hiçbir canlı çevresinden bağımsız olarak düşünülmemektedir. İnsan var olduğundan beri çevreyi kendi yaşamını sürdürmek amacıyla kullanmış (Ağacan, 2014), gelişimi ve ilerlemeyi hedef edinerek, konforlu ve güvenli bir ortam sağlamak için çevresini sürekli geliştirmiş ve değiştirmiştir. Teknolojik gelişmelerle birlikte keşfedilen yeni ürünler günlük hayatın kaçınılmaz bir parçası olmuştur (Atıl vd., 2005). İnsan, çevre ile arasına mesafe koyamamış, aksine bütünleşmiş; doğayı ve doğal kaynakları tahrip edici etkilere neden olmuştur. İnsan-doğa bütünleşmesi sonucu bozulan doğal denge, ekolojik döngüyü etkilemiş ve çevresel dengenin korunamaması insan dâhil pek çok canlının yaşamını tehlikeye sokan çevre sorunlarını gündeme getirmiştir (Uslu, 2011; Gül, 2013). Tüm insanlığı tehdit eden küresel çevre sorunlarının başlıca nedeni, hızlı nüfus artışına bağlı olarak gerçekleşen kentleşmedir. Kentleşme, insanlığın doğaya aşırı müdahalesi sonucu oluşan ve doğal kaynakları en çok tehdit eden gelişmelerden birisidir. Kor (2011)'e göre ekosistemin işleyişini dikkate almayan kentleşme, doğal alanları parçalayarak habitat değerlerini azaltmakta ve ekolojik sürekliliği olumsuz etkilemektedir. Bütün bu gelişmeler, ortaya çıkan kentsel peyzajların ekolojik fonksiyonlarını yerine getirmekte zorlanacağı durumlara sebep olmaktadır. Bu sebeple kentler doğal ve doğal olmayan çeşitli problemlerle karşı karşıya kalmaktadır.

Kentleşme, kentsel yayılma, hızlı demografik değişimler ve yaban yaşamına müdahale edilmesi gibi etmenler insan sağlığını etkileyen durumlar ortaya koymaktadır. Dazsak’a göre (t.y.) son 30-40 yıl içerisinde ortaya çıkan salgınlar, yaban yaşamına müdahale edilmesi ve demografik değişikliklerin bir sonucu olarak ortaya çıkmaktadır (URL-1, 2020). Di Marco vd. (2020)'ye göre habitat kayıpları, yaban yaşamına müdahale ve genel olarak biyolojik çeşitlilikteki azalma, yeni görülebilecek bulaşıcı hastalıkların yayılmasına etki etmektedir. Bu durum aşağıda belirtilen şekillerde gerçekleşebilmektedir:

- Konakçı türlerin daha yaygın hale gelmesi,

- Sulama kanalları ve barajlar gibi hastalık üreme alanlarının çoğalması,

- Yaban türlerinin birbirleriyle ve evcil hayvanlarla yakın temasi,

- Farklı türlerin arasındaki patojen geçişi,

- Avc1 türlerin yok olmasi,

- İnsan müdahalesiyle meydana gelen genetik değişiklikler,

- Bulaşıcı hastalık ajanlarının neden olduğu çevre kirliliği (WWF, 2020).

İnsanlığın doğaya aşırı müdahalesi sonucu, her yıl iki ile dört virüs çeşidinin ortaya çıktığı belirtilmektedir (URL-2, 2020). 31 Aralık 2019 tarihinde, Çin'in Wuhan kentinde ortaya çıkan ve nedeni bilinmeyen bir şekilde solunum yolu hastalığına sebep olan bir virüs DSÖ’ye bildirilmiştir (DSÖ, 2020a). Bu bildirim ardından yapılan çalışmalar virüsün zoonotik (hayvanlardan insanlara geçen) bir kaynağa sahip olduğunu göstermektedir (DSÖ, 2020b). Virüsün dünyada hızla yayılmaya başlaması sebebiyle, 11 Mart 2020'de DSÖ tarafindan küresel ölçekte pandemi ilan edilmiştir (DSÖ, 2020a). Pandemi, Dünya çapında veya oldukça geniş bir alanda, uluslararası sınırları aşan ve genellikle çok sayıda insanı etkileyen bir salgın olarak tanımlanmaktadır (Last, 2001). Koronavirüs olarak adlandırılan (daha önce 2019-nCoV olarak bilinen ve daha sonra COVID-19 olarak belirtilen) salgın, küresel bir sağlık krizine dönüşmüştür. İlk vaka tespiti 31.12.2019 tarihinde Çin'de yapılan virüsün, 21 Temmuz 2020 itibariyle Dünya genelinde DSÖ'ye bildirilen, 603.691'i ölümle sonuçlanan 14.348.858 vakası bulunmaktadır (DSÖ, 2020a; DSÖ, 2020c). Ülkelere göre onaylı vaka ve ölüm sayılarına ilişkin veriler vaka sayısına göre çoktan aza doğru sıralanarak Tablo 1'de verilmiştir.

Tablo 1. Ülkelere göre onaylı vaka ve ölüm sayılarına ilișkin veriler (DSÖ, 2020c)

\begin{tabular}{llcc}
\hline & Vaka Sayısına Göre Ülke Sıralaması & Onaylı Vaka Sayısı & Ölüm sayısı \\
\hline $\mathbf{1}$ & Amerika & 3.685 .460 & 139.460 \\
$\mathbf{2}$ & Brezilya & 2.074 .860 & 78.772 \\
$\mathbf{3}$ & Hindistan & 1.118 .043 & 27.497 \\
$\mathbf{4}$ & Rusya & 777.486 & 12.427 \\
$\mathbf{5}$ & Güney Afrika & 364.328 & 5.033 \\
$\mathbf{6}$ & Peru & 349.500 & 12.998 \\
$\mathbf{7}$ & Meksika & 338.913 & 38.888 \\
$\mathbf{8}$ & Şili & 330.930 & 8.503 \\
$\mathbf{9}$ & İngiltere & 294.796 & 45.300 \\
$\mathbf{1 0}$ & İran & 273.788 & 14.188 \\
$\mathbf{1 1}$ & Pakistan & 265.083 & 5.599 \\
$\mathbf{1 2}$ & İspanya & 260.255 & 28.420 \\
$\mathbf{1 3}$ & Türkiye & 219.641 & 5.491 \\
\hline
\end{tabular}


COVID-19 her yaştan insanı enfekte etmektedir, fakat bugüne kadarki veriler iki grup insanın hastalığa yakalanma riskinin daha yüksek olduğunu göstermektedir. Bunlar çoğunlukla yaşlı insanlar (60 yaşın üzerindeki insanlar) ile belirli hastalıkları ve hastalık geçmişleri olan (kanser, kronik solunum hastalıkları, diyabet vb.) insan gruplarıdır. DSÖ, virüsün yayılmasını engellemek için herkesin COVID-19'dan korunması gerektiğini vurgulamaktadır (DSÖ, 2020d). DSÖ’nün 716.570 vaka sayısı üzerinden cinsiyet ve yaş aralıklarına göre yayınladığı grafik Şekil 1'de verilmiştir. Şekilden yola çıkılarak COVID-19'un yayılımında cinsiyet faktörünün belirleyici bir unsur olmadı̆̆ 1 ifade edilebilir.

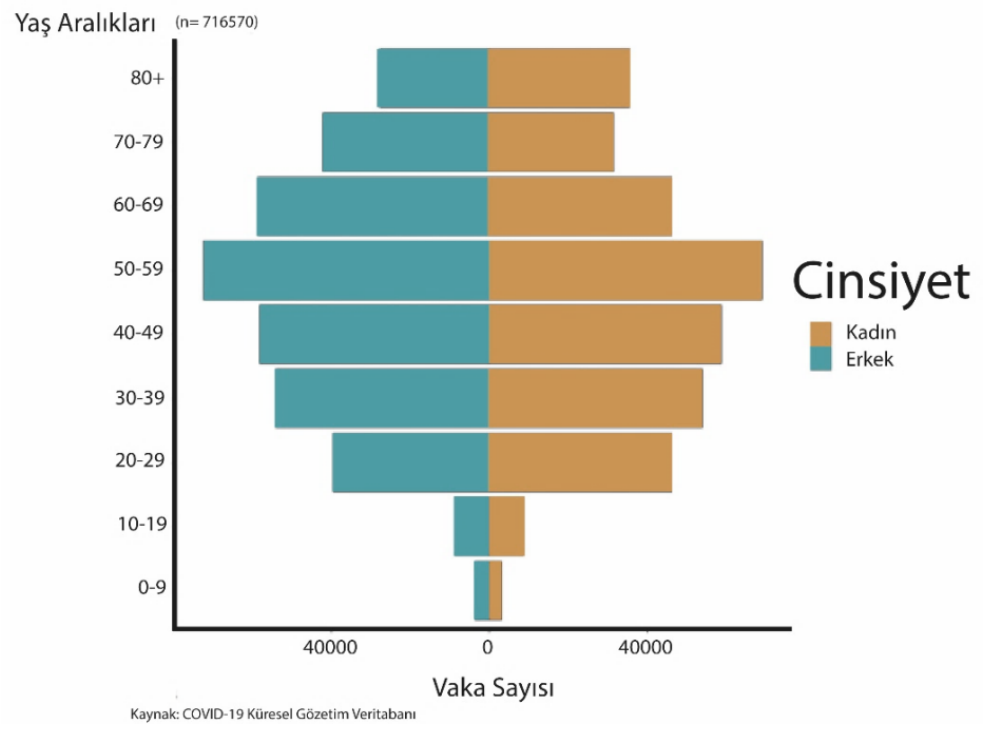

Şekil 1. Vaka sayısının yaş ve cinsiyete göre dağılımı (DSÖ, 2020e'den alınarak Türkçeleştirilmiştir).

Virüsün yayılmasını önlemek ve yayılma hızını kontrol altına almak amacıyla eğitim kurumları geçici olarak kapatılmış ve birçok eğitim kurumunda uzaktan eğitime geçilmiştir. Küresel ölçekteki bu kapanmalar, dünyadaki öğrenci nüfusunun \%70'inden fazlasını etkilemektedir (UNESCO, 2020). Okulları kapatma kararı, bulaşmayı azaltmanın yanı sıra potansiyel vaka sayılarının yüksek ekonomik ve sosyal maliyetleri ile sağlık gibi kilit hizmetlerin olası aksamalarına karşı alınan bir önlemdir (Cauchemez vd., 2009).

Salgınlar tarih boyunca yönetim ve yaşam değişikliklerine yol açan ve dünya çapında etkileri olan olaylardır. Tarihteki salgınlar, beslenme şekilleri, imparatorlukların yıkımı, mimariyi şekillendirmesi gibi birçok konuda yeni gelişmelerin nedeni olarak kabul edilmiştir (Şeker vd., 2020). Harris (1994)'e göre birçok yazar ve düşünür salgının, nüfus artışını engelleyerek günümüz Avrupa'sının refah düzeyi ile kent mimarisini değiştirdiğini, halk sağlığına katkı sunduğunu ve ormanları koruduğunu savunmaktadır (Özden ve Özmat, 2014). Tarihte karşılaşılan salgınların planlama ve tasarım yöntemleriyle ilişkilendirilmiş olarak, toplum sağlı̆̆ını destekleyen etkileri de bulunmaktadır. Sennett (2018)'e göre kentlerin sıhhi koşullarının iyileştirilmesi; plancıları, mimarları ve mühendisleri 19. yüzyılın sonlarında kentleri yeniden tasarlamaya motive etmiştir. 1990'lardan bu yana sağlık ve kent planlaması ilişkisine karşı ilgi artışı gözlenmiş, bu alan peyzaj mimarlığı, şehir ve bölge planlama, halk sağlığı ve çevre psikolojisi gibi çeşitli disiplinlerden akademisyenler tarafından beslenmiştir (Honey-Roses vd., 2020).

Salgının yayılma hızına etki etmeye çalışan ülkeler dış mekân kullanımını engellemek, seyahat kısıtlamaları getirmek, vatandaşlarını karantinaya almak, spor ve konser etkinlikleri gibi büyük toplantıları iptal etmek gibi önlemler alarak kentsel ve kırsal ortam dinamiklerini değiştirmektedir (UNDP, 2020). Fakat sürdürülebilirliklerinin sağlanmasını karmaşık altyapı/üstyapı sistemleri ile sosyal olaylara dayandıran ve bu sistemlere güvenen kentler, küresel ya da yerel saldırılara karşı savunmasız durumdadır. Ortaya çıkan COVID19 krizi, kentlerin iklim değişikliği ve doğal afetler kadar gıda güvenliği ve salgın hastalıklar gibi doğal olmayan afetler için uzun vadeli çözüm yöntemleri gerektiren problemlerle de karşı karşıya olduklarını göstermektedir (Çörek Öztaş, 2020). Kentsel mekânlarda sosyal mesafenin çok az olmasıyla hızlı bir şekilde yayılan COVID19 pandemisinin bir kentleşme sorunu olarak değerlendirilmesi gerektiği belirtilmektedir. Bulaş hızının çok yüksek olduğu belirtilen salgının önlenmesinde hijyen ve sosyal mesafeyi koruma uygulamaları en önemli unsurlar olarak kabul edilmektedir. Fakat çarpık kentleşmeyle ortaya çıkan sağlıksız ortamlarda sosyal mesafenin korunması ve buna yönelik önlemlerin uygulanması pek mümkün olmamaktadır (URL-3, 2020). Gıda yetersizliği, temizlik durumu, iklim koşulları, yerleşme yoğunluğu, yerleşim alanları gibi birçok çevresel faktör salgınların yayılım hızında etkilidir (Yiğit ve Gümüşçü, 2016). Sosyal bir varlık olan insan, salgın 
hastalık risklerinden dolayı evde kalıp, zorunlu olmadıkça kentsel mekânları kullanmamakta, kamusal alan kullanımlarını ve rekreasyon aktivitelerini gerçekleştirememektedir. Brooks vd. (2020)'ye göre COVID-19 nedeniyle sosyal uzaklığa bağlı izolasyonun özellikle yalnız yaşayan insanlar üzerinde travmatik stres semptomlarına neden olabileceği belirtilmiştir (Samuelsson vd., 2020). Kent planlamasının zayıf olduğu ve hızla büyüyen nüfusun ihtiyaçlarını karşılama kapasitesinin düşük olduğu kentsel merkezlerin hızlı büyümesi, gecekondu mahallelerinin/ kentlerinin gelişmesine yol açmaktadır. Büyük ölçüde kalabalık olan gecekondu alanları da konut koşulları, arıtılmış su bulunmaması ve sanitasyon tesislerinin eksikliği sebebiyle salgının yayılma hızına etki eden ortamlardır (Reyes vd., 2013).

Ülkemizde salgının yayılımın takip edilmesi ve önlenmesi amacıyla Sağlık Bakanlığı tarafından geliştirilen "Hayat Eve Sığar” uygulaması, COVID-19 açısından riskli bölgelerin görüntülenebildiği bir mobil uygulamadır. $\mathrm{Bu}$ mobil uygulama için geliştirilen "Salgın Risk Haritaları”nda vaka sayısının yüksek olduğu noktaların belirtilmesiyle birlikte salgının kontrol altında tutulması amaçlanmaktadır (Yanık ve Günyol, 2020). Salgının ilerleyişinin yavaşlatılmasında yenilikçi uygulamaların önemi büyüktür. Ancak, ortaya çıkabilecek yeni bir salgın durumuna karşın kentsel sistemlerin güçlendirilmesi de önem taşımaktadır. COVID-19, kentsel sistemlerin güçlendirilmesi ihtiyacının acil olduğuna dair önemli bir göstergedir (Lee vd., 2020). Bu çalışma doğal ve doğal olmayan tüm tehlikelere karşı kentsel ve bölgesel planlamanın gerekliliğine dikkat çekilmesi amacıyla yapılmıştır

\section{Materyal ve Metot}

\subsection{Materyal}

Çalışmanın birincil materyalini, çalışma amacına yönelik veri sağlamak adına araştırma konusuna ilişkin yapılan literatür taramasıyla elde edilen veriler oluşturmuştur. Çalışmaya altlık olan konular ile güncel bir konu olan COVID-19'a ilişkin ulusal ve uluslararası bilimsel yazılar incelenmiş, web kaynakları ve fotoğraflardan yararlanılmıştır.

\subsection{Metot}

Çalışmanın yöntemi veri toplama, analiz ve değerlendirme aşamalarından oluşmaktadır. Bu çalışmada insançevre ve salgın konularına ilişkin genel ve mekânsal algının değerlendirilebilmesi için anket çalışması gerçekleştirilmiştir. Anket çalışması SPSS 23.0 programında değerlendirilmiştir. Öncelikle demografik veriler değerlendirilmiş daha sonra, insan-peyzaj ve salgın arasındaki ilişkinin ölçülmesine yönelik önermeler değerlendirilerek "Pandemi faktörünün peyzaja etkilerine ilişkin tespitlerde" bulunulmuştur. Çalışmada anketin geçerliliğini gösteren Cronbach Alfa testi yapılmış ve anket güvenilir bulunmuştur. Araştırmanın son aşamasında ise, salgın hastalıklar gibi doğal olmayan afetler için uzun vadeli çözüm yöntemlerine gereksinim duyulması nedeniyle yeni dış mekân kullanımlarına, toplum sağlığının iyileştirilmesine ve yetkili kurumlara yönelik önerilere yer verilmiştir.

\section{Bulgular}

Anket çalışmasının değerlendirilmesinde, öncelikle demografik veriler analiz edilmiş daha sonra, insan/peyzaj ve salgın arasındaki ilişkinin ölçülmesine yönelik önermeler değerlendirilerek pandemi faktörünün peyzaja etkilerine ilişkin tespitlerde bulunulmuştur. Tablo 2'ye göre, ankete katılan 198 kişiyi "Diş mekân planlama/tasarım ve yönetimi”, “Çevre koruma”, "Sağlık” ve "Diğer” başlıklar altında değerlendirilen kişiler oluşturmaktadır. Bu kişilerin \%19,2'si çevre ile ilgili Sivil Toplum Kuruluşları (STK)'nda yer almaktadır. Yaş dağılımları incelendiğinde ankete katılanların çoğunluğunun \%47,5 ile 21-30 yaş aralığında; en az katılımcının ise $\% 2$ ile 65 yaş aralığında olduğu görülmektedir. 
Tablo 2. Demografik veriler ve oranları

\begin{tabular}{clrr}
\hline & Demografik veriler & Frekans (198 kişi) & Yüzde (100) \\
\hline \multirow{2}{*}{ Cinsiyet } & Kadın & 145 & 73,2 \\
& Erkek & 53 & 26,8 \\
& $18-20$ & 16 & 8,1 \\
& $21-30$ & 94 & 47,5 \\
Yaş & $31-40$ & 29 & 14,6 \\
& $41-50$ & 31 & 15,7 \\
& $51-64$ & 24 & 12,1 \\
& 65 yaş ve üstü & 4 & 2,0 \\
Çocuk Sahibi & Var & 80 & 40,4 \\
Olma Durumu & Yok & 118 & 59,6 \\
& D1ş mekân planlama/tasarım ve & & 22,7 \\
& yönetimi ile ilgili & 45 & 4,5 \\
Meslek & Çevre koruma ile ilgili & 9 & 11,6 \\
& Sağlı çalışanı & 23 & 61,1 \\
& Diğer & 121 & 19,2 \\
STK'da Yer & Evet & 38 & 80,8 \\
\hline Alma Durumu & Hayır & 160 & \\
\hline
\end{tabular}

“İnsan ve peyzaj ayrılmaz bir bütündür”, “İnsanlar doğayı ve kaynaklarını sömürmektedir” ve "İnsanın çevreyi pandemi sebebiyle alıştı̆̆ı şekilde kullanamaması doğanın lehinedir” önermelerine katılımcılar sırasıyla \% 49,7 \%68,2 ve \%46,5 oranında tamamen katıldıklarını belirtmişlerdir (Tablo 3). Avrupa Peyzaj Sözleşmesi (APS)'ne göre; peyzaj, insanlar tarafından algılandığı şekliyle karakteri, doğal veya insan faaliyetleri dâhilinde şekillenen bir alandır (APS, 2003). İnsan ve peyzaj arasındaki bu karşılıklı olumlu/olumsuz etkileşimlerin katılımcılar tarafından da doğrulandığı görülmektedir. Bu önermelerden yola çıkarak insan eliyle gerçekleştirilen faaliyetlerin doğa tahribatının varlığı ve çevresel sorunların insan kaynağına bağlı olduğu konusunda genel bir kanı olduğu görülmektedir. COVID-19'un yayılması sonucunda ABD'nin ana bölgelerinde hava kirliliğinde önemli düşüşler görülmüş, bu düşüşlerin gözlenmesinde toplulukların sokağa çıkmasındaki kısıtlamaların etkili olduğu belirtilmiştir (Şekil 2) (NASA, 2020).

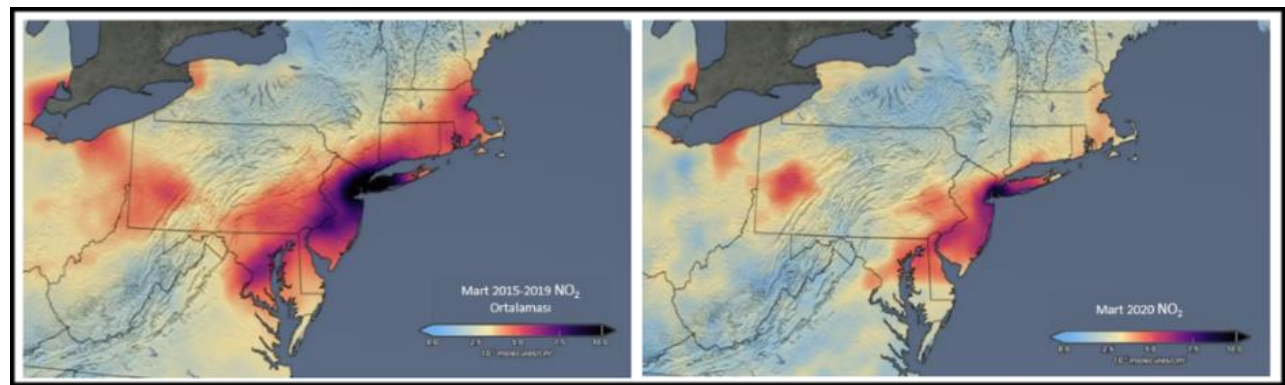

Şekil 2. Kuzeydoğu ABD’nin Mart ayı 2015-2019 Yıllarına ait Troposferik $\mathrm{NO}_{2}$ ortalamaları ile 2020 Mart ayı Troposferik $\mathrm{NO}_{2}$ ortalamasının uydu görüntüleri (NASA, 2020'dan alınarak Türkçeleştirilmiştir).

Tablo 3'te "İnsanların yaşam alanları daraldıkça, yaban hayvanları yaşam alanlarını genişletmektedir" önermesine katılımcıların \%38,9'u, “İnsanların yaşam alanları daraldıkça, bitki türleri yaşam alanlarını genişletmektedir" önermesine katılımcıların \%44,4'ü tamamen katıldıklarını ifade etmişlerdir. İnsanların pandemi sebebiyle doğayı ve kaynaklarını eskisinden daha az kullanmaları canlı türlerinin ve doğanın nefes almasına olanak sunmuştur (WWF, 2020). İnsanların bu önermeleri desteklemeleri, doğanın yeniden uyanışına tanık olduklarını göstermektedir. Özellikle insan müdahaleleri sonucu yaşam ortamları gitgide azalan yaban yaşamının insansız kalan kentlerde görülmeye başlamaları bu önermeleri desteklemektedir (Şekil 3). 


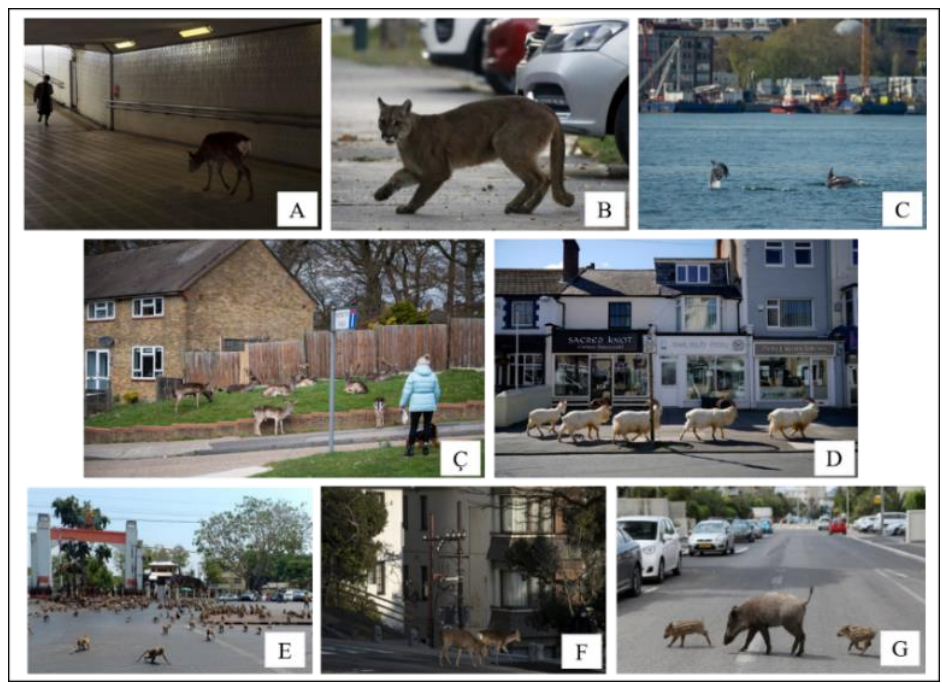

Şekil 3. A) Nara/JAPONYA B) Santiago/ŞİLİ C) İstanbul/TÜRKİYE Ç) Romford/İNGİLTERE

D) Llandudno/GALLER E) Lopburi/ TAYLAND F) Nara/JAPONYA G) Haifa/ISRAİL (URL4, URL-5, URL-6, URL-7, URL-8, URL-9, URL-10, URL-11, 2020).

“İnsanların içinde bulunduğu peyzaj, pandeminin ilerleme hızına etki etmektedir” önermesine kişiler \%39,1 oranında katılırken, "Pandemiyle mücadele tekniklerimizin (kullanılan kimyasallar) çevre üzerinde olumsuz etkileri vardır" önermesine \%31,3 oranında katıldıklarını ifade etmişlerdir (Tablo 3). Değerliyurt ve Çabuk (2015)'e göre, insanların peyzaja hatalı müdahaleleri, peyzajın değerinin yitirmesine neden olmaktadır. Sorulara sırasıyla \%22,3 ve \%21,2 oranlarında verilen orta derecede katılıyorum yanıtları, insanların doğa üzerindeki etkilerinin yeteri kadar farkında olmamalarından kaynaklanıyor olabilir. Özgüner (2009)'a göre, insanların doğa ile iç içe bulunması psikolojik ve fizyolojik sağlıklarına fayda sunmaktadır. Bu kapsamda "Dış mekân kullanımı ile ilgili, sınırlandırma ve yasaklar insanlar üzerinde psikolojik baskı yaratmaktadır” önermesine kullanıcıların büyük çoğunluğunun katılması da bu görüşü doğrular niteliktedir.

"İnsanların çevre ile ilişkisinin sınırlandırılması rekreatif alışkanlıklarında değişime neden olur” önermesine \%49,2 ile katıldıkları, "Pandemi durumu insan ve çevre ilişkisinde olumlu farkındalıklara neden olacaktır" önermesine \%30,8 ile tamamen katıldıkları ve "Pandemi, insanların dış mekân kullanımlarında önemli değişikliklere neden olur” önermesine \%52,0 ile katıldıkları belirlenmiştir (Tablo 3). Pandemi sırasında kamusal alanlardaki dış mekân kullanımları bazı önlemlerle gerçekleştirilmektedir. Bu önlemlerden biri açık-yeşil alanlarda uygulanan "sosyal mesafe çemberi” çizimidir (Şekil 4). Böylece insanların birbiriyle ve çevresiyle olan ilişkileri sınırlandırılarak olumsuz etkilerin kontrol altına alınması amaçlanmaktadır.

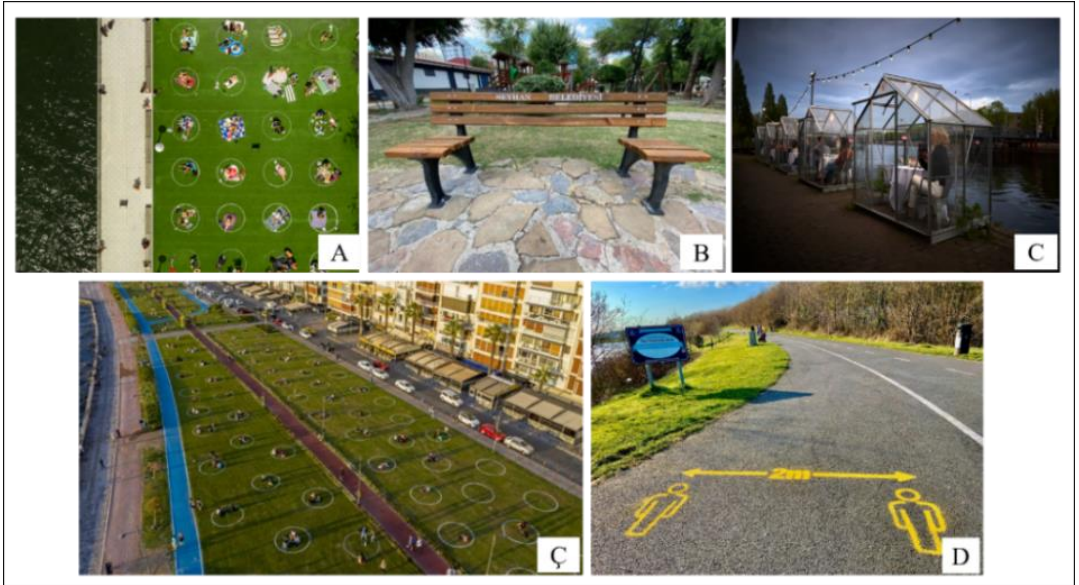

Şekil 4. A) New York/ ABD B) Adana/TÜRKIYYE C) Amsterdam/HOLLANDA Ç) İzmir/TÜRKİYE D) Dundalk/İRLANDA (URL-12, URL-13, URL-14, URL-15, URL-16, 2020).

Erez (2003)'e göre; kentsel mekân, davranış örüntülerinin oluşturduğu kullanım biçimleri ve sıklığı ile mekânsal bir kimlik kazanmaktadır. Kültür ise davranış kalıplarının ve değerlerin tekrarlanmasıyla mekânda yerini almaktadır. Bu bağlamda kişilerin; "Pandemi, insanların topluluk içindeki davranışlarında değişikliklere neden 
olacaktır ve pandeminin etkisi geçtikten sonra insanlık eski davranış biçimine geri dönecektir” önermelerine katılmaları mekân kullanımına ilişkin kültürün değişime uğramayacağına dair bir gösterge olabilir (Tablo 3).

Tablo 3. Pandemi ve peyzaj ilişkisini ölçmeye yönelik önermelerin sıklık dağılımları

\begin{tabular}{|c|c|c|c|c|c|c|c|c|}
\hline & Önermeler & 1 & 2 & 3 & 4 & 5 & Ort. & S.S \\
\hline $\mathbf{1}$ & İnsan ve peyzaj ayrılmaz bir bütündür. & 4,0 & 2,5 & 9,1 & 34,5 & 49,7 & 4,23 & 1,00 \\
\hline 2 & İnsanlar doğayı ve kaynaklarını sömürmektedir. & 3,0 & 0,5 & 6,1 & 22,2 & 68,2 & 4,52 & 0,87 \\
\hline 3 & $\begin{array}{l}\text { İnsanın çevreyi pandemi sebebiyle alıştığı şekilde } \\
\text { kullanamaması doğanın lehinedir. }\end{array}$ & 1,5 & 3,5 & 11,6 & 36,9 & 46,5 & 4,23 & 0,89 \\
\hline 4 & $\begin{array}{l}\text { İnsanların yaşam alanları daraldıkça, yaban hayvanları } \\
\text { yaşam alanlarını genişletmektedir. }\end{array}$ & 2,5 & 6,1 & 12,6 & 39,9 & 38,9 & 4,06 & 0,99 \\
\hline 5 & $\begin{array}{l}\text { İnsanların yaşam alanları daraldıkça, bitki türleri yaşam } \\
\text { alanlarını genişletmektedir. }\end{array}$ & 1,5 & 1,5 & 11,1 & 41,4 & 44,4 & 4,25 & 0,83 \\
\hline 6 & $\begin{array}{l}\text { Pandeminin ilerlemesinde, insanların neden olduğu } \\
\text { çevre sorunlarının etkisi büyüktür. }\end{array}$ & 2,5 & 9,1 & 21,2 & 33,8 & 33,3 & 3,86 & 1,05 \\
\hline 7 & $\begin{array}{l}\text { Pandeminin çevre üzerinde (hava, su ve toprak) olumlu } \\
\text { etkileri vardır. }\end{array}$ & 3,0 & 8,6 & 16,2 & 42,9 & 29,3 & 3,86 & 1,02 \\
\hline 8 & $\begin{array}{l}\text { İnsanların içinde bulunduğu peyzaj, salgının ilerleme } \\
\text { hızına etki etmektedir. }\end{array}$ & 9,1 & 17,8 & 22,3 & 39,1 & 11,7 & 3,26 & 1,15 \\
\hline 9 & $\begin{array}{l}\text { Pandemiyle mücadele tekniklerimizin (kullanılan } \\
\text { kimyasallar) çevre üzerinde olumsuz etkileri vardır. }\end{array}$ & 4,5 & 10,1 & 21,2 & 31,3 & 32,8 & 3,77 & 1,14 \\
\hline 10 & $\begin{array}{l}\text { Dış mekân kullanımı ile ilgili, sınırlandırma ve yasaklar } \\
\text { insanlar üzerinde psikolojik baskı yaratmaktadır. }\end{array}$ & 1,0 & 6,1 & 6,6 & 44,4 & 41,9 & 4,2 & 0,88 \\
\hline 11 & $\begin{array}{l}\text { İnsanların çevre ile ilişkisinin sınırlandırılması rekreatif } \\
\text { alışkanlıklarında değişime neden olur. }\end{array}$ & 1,0 & 2,0 & 21,3 & 49,2 & 26,4 & 3,97 & 0,80 \\
\hline 12 & $\begin{array}{l}\text { Pandemi, insan ve çevre ilişkisinde olumlu } \\
\text { farkındalıklara neden olacaktır. }\end{array}$ & 3,0 & 8,6 & 20,7 & 36,9 & 30,8 & 3,83 & 1,05 \\
\hline 13 & $\begin{array}{l}\text { Pandemi, insanların dış mekân kullanımlarında önemli } \\
\text { değişikliklere neden olur. }\end{array}$ & 2,5 & 4,0 & 16,2 & 52,0 & 25,3 & 3,39 & 0,89 \\
\hline 14 & $\begin{array}{l}\text { İnsanların çevre ile ilişkisinin sınırlandırılması kültürel } \\
\text { bir değişime neden olmaz. }\end{array}$ & 23,2 & 26,8 & 23,2 & 20,2 & 6,6 & 2,60 & 1,22 \\
\hline 15 & $\begin{array}{l}\text { Pandemi, insanların topluluk içindeki davranışlarında } \\
\text { değişikliklere neden olacaktır. }\end{array}$ & 1,5 & 4,5 & 15,7 & 51,5 & 26,8 & 3,97 & 0,86 \\
\hline 16 & $\begin{array}{l}\text { Pandeminin etkisi geçtikten sonra insanlık eski davranış } \\
\text { biçimine geri dönecektir. }\end{array}$ & 8,1 & 15,2 & 32,8 & 29,8 & 14,1 & 3,26 & 1,12 \\
\hline
\end{tabular}

\section{Sonuç ve Öneriler}

Tarih boyunca salgın hastalıkların insanlık için önemli problemler teşkil ettiği bilinmektedir (Koyuncu, 2008). 21. yüzyılda ortaya çıkan COVID-19 pandemisi de insanlık için önemli dönüm noktalarından biridir. İçinde bulunulan salgın durumu kişilerin kamusal alanla etkileşimini zayıflatmış, doğal ve yapay peyzajdan da soyutlanmalarına neden olmuştur. Salgın, plancı ve tasarımcıları mekânları, sosyal yoğunluk, mesafe kuralı veya halk sağlığı konularında riskleri tanımlayan yeni tipolojiler oluşturmaya itmektedir. Van der Berg (2020)’ye göre, dışarı çıkma kısıtlaması olan kentlerde yeşil alanlar, özellikle küçük mahalle parkları daha fazla kullanılmaktadır. Salgın durumu, kentlerde alışık olunan yeşil alanların türlerini, dağılımını ve yeşil alanların ne sunması gerektiği konusundaki beklentileri değiştirmektedir (Honey-Roses vd., 2020). Değişen beklenti ve öncelikler dolayısıyla kentsel mekânın salgın gibi yapay afetlere yönelik önlemleri de içerecek bir şekilde planlanması, tasarımı ve yönetiminde peyzaj mimarlarının rolü büyüktür. Çalışma kapsamında dış mekân kullanımlarına, toplum sağlı̆ııın iyileştirilmesine ve yetkili kurumlara yönelik gerçekleştirilen öneriler yararlanılan kaynaklara göre Tablo 4’te sunulmuştur. 
Tablo 4. Salgın durumlarında dış mekân kullanımlarına, toplum sağlığının iyileştirilmesine ve yetkili kurumlara yönelik öneriler.

\section{MEKÂNA YÖNELİK}

- DSÖ, kentlerde kişi başına en az $9 \mathrm{~m}^{2}$ yeşil alan bulunmasını ve ideal kentsel yeşil alan değerinin kişi başına $50 \mathrm{~m}^{2}$ olması gerektiğini belirtmektedir (Russo ve Cirella, 2018). Türkiye'de Mekânsal Planlar ve Yayın Yönetmeliği (2014) kişi başına düşen açık ve yeşil alan değerini $10 \mathrm{~m}^{2}$ olarak belirtse de, yüksek nüfusa sahip birçok kent bu standartları taşımamaktadır. Afet durumlarında insan sağlığı üzerinde etkileri bulunan kentsel yeşil alan değeri arttırılmalı ve buna yönelik denetimler yapılmalıdır.

- Salgın gibi afet durumlarında bir kentin gıda güvenliğini de sağlayabilmesi gereklidir. Bu sebeple gıda güvenliğinin yanında çevresel, toplumsal ve ekonomik faydaları olan kentsel tarım alanları kentsel arazi kullanımı olarak değerlendirilmelidir (Açıksöz vd., 2019).

- Mekân tasarımından kentsel donatı seçimlerine sade, basit, kullanışlı ve sosyal mesafeyi korumaya yardımcı kompakt fikirler uyarlanmalıdır. Donatılar bireysel kullanım veya sosyal mesafeyi koruyan aralıklar göz önünde bulundurularak konumlandırılmalıdır.

- Virüsün yayılımının önlenmesi amacıyla, salgın risk haritalarının kapsamı geliştirilmelidir (PMO, 2020).

- Kentsel hava kalitesinin artırılması ve canlı türlerinin korunması adına yeşil alt yapı uygulamalarına yer verilmelidir (PMO, 2020).

- Kentsel hava kalitesinin artırılması için ulaşım alternatiflerinin sunulması ve doğa dostu ulaşım (bisiklet) olanakları arttırılmalıdır.

- Kentsel yayılmanın önüne geçilmesi ve kırsal yaşantının korunması için peyzaj parçalanmasının önlenmesi/iyileştirilmesine yönelik planlama çalışmalarına yer verilmelidir.

- Cvejic vd. (2015) ile Rupprecht ve Byrne (2014)'e göre doğal ve doğal olmayan afet durumlarının şekillendirdiği yeni kentsel mekân tipolojileri geliştirilmelidir (korunaklı küçük mahalle parklarının, cep parklarının yaygınlaştırılması, kapsamların genişletilmesi gibi) (Honey-Roses vd., 2020).

- Salgınlar dolayısıyla değişen açık-yeşil alan kullanım biçimlerine yönelik koşu parkurları ve yolların genişletilmesi, alternatif güzergâhların oluşturulması gibi çeşitli çözümlemeler gerçekleştirilmelidir. Yollarda ve parkurlarda sosyal mesafenin korunmasının gerekliliği çizilen sınırlar veya çeşitli uyarılarla belirtilmelidir (Honey-Roses vd., 2020).

\section{TOPLUM SAĞLIĞININ IYYILEŞTIRILILESINE YÖNELIKK}

- Doğaya görsel erişimin sağlık açısından önemli fiziksel ve zihinsel yararları bulunduğu bilinmektedir. Bu sebeple kentlerde bu tür doğal afet ve salgın durumları için daha hareketli alanlardan daha korunaklı yerler olarak hizmet veren daha küçük yeşil alanlar veya mahalle parkları bulunmalıdır (Bu korunaklı alanlar yeşil alanlar veya gri alanlar olabilir, küçük bir park veya bir sokak olarak da tasarlanabilir.) (Honey-Roses vd., 2020).

- Fiziksel aktivite oranının artırılması amacıyla kentsel dolaşım sistemleri iyileştirilmelidir (PMO, 2020).

- Salgınların yayılmasını önlemek ve kişilerin sağlığının korunmasının desteklenmesi amacıyla, tarama testlerinin artırılması ve yaygınlaştırılması gerekmektedir.

- Topluluk odaklı çözümlerin geliştirilmesi, dayanışmayı sağlayan yerel örgütlerin desteklenmesi, mahalle ölçeğinden diğer ölçeklere kadar bilimsel, kanıtlanabilir ve şeffaf verilerin üretilmesi, bilgiye dayanan karar alma süreçlerinin sağlanması ve sosyo-ekonomik yapıya olan etkinin azaltılması gerekmektedir (Çılgın, 2020).

\section{YETKILİ KURUMLARA YÖNELIK}

- Planlama ve halk sağlığı uzmanları bu kriz sırasında ve sonrasında daha sağlıklı kentler inşa etmek için bir araya gelmelidir (Honey-Roses vd., 2020).

- Salgının yayılım hızının kontrolü adına, salgın ve afet yönetimi planları revize edilmelidir.

- Salgın kontrol ve yönetimine ilişkin eğitimler düzenlenmelidir.

- Toplumun bilinçlenmesi adına, STK'ların salgın yönetimi ile ilgili faaliyetler gerçekleştirmesi gerekmektedir.

Bugünkü kentsel alanların ve yapıların gelişim ve devingenlik sürecinde, geçmişte yaşanan salgınların etkisi bulunmaktadır. Bugün içinde bulunulan pandemi süreci de dünya mimarisi ve kent planlamasında etkili olacaktır (Erdem, 2020). Pandeminin kentsel mekâna etkisinin incelendiği araştırma kapsamında, mekânın çeşitli çevresel 
faktörler dâhilinde şekillendiği ve bu şekillenmelerin mekân kullanımına yönelik kültürü bir nebze de olsa etkilediği düşünülmektedir. Çalışma, kentsel mekânın az kullanılması ya da kullanılmaması durumunun "doğanın lehine" olduğunu gösterse de insan ve doğanın bağımsız iki varlık olamayacağı da bilinen bir gerçektir. Çünkü yaşayan kentsel mekânların, insanlar kullandığı sürece var olduğu düşünülmektedir.

\section{Kaynaklar}

1. Açıksöz, S., Dal, İ., M. Ö. Özbek (2019). Kentsel Tarımın Seyri ve Yenilikçi Uygulamalar. Plant Peyzaj ve Süs Bitkiciliği Dergisi, Yıl: 9, Say1: 31-32, 48-52. Haziran-Kasım.

2. Ağacan, İ. (2014). Çevre Kirliliği Sorunları ile Mücadelelerde Türkiye'de Uygulanan Çevre Vergileri ve Çevre Vergisi Bilinci. Yüksek Lisans Tezi (yayınlanmamış), Sakarya Üniversitesi Sosyal Bilimler Enstitüsü, 152s.

3. APS (2003). Avrupa Peyzaj Sözleşmesi, http://docplayer.biz.tr/8214363-Avrupa-peyzajsozlesmesi.html, (30.06.2020).

4. Atıl, A., Gülgün, B., Yörük, İ. (2005). Sürdürülebilir Kentler ve Peyzaj Mimarlı̆̆ı. Ege Üniversitesi Ziraat Fakültesi Dergisi, 42(2), 215-226.

5. Cauchemez, S., Ferguson, N. M., Wachtel, C., Tegnell, A., Saour, G., Duncan, B., Nicoll, A. (2009). Closure of Schools During an Influenza Pandemic. The Lancet Infectious Diseases, 9(8), 473-481.

6. Çılgın, K. (2020). Yerelliğin Pandeminin Etkileri Karşısında Artan Önemi ve Mahalle Parantezinde Dayanışma ve Planlamanın Geleceği. Spektrum. Pandemide Kentsel Sistem: Yaşama, Çalışma ve Sosyalleşme Mekânlarında Yeni Standartlara Doğru (Yayına hazırlayanlar: Sema Ergönül, İnci Olgun, Serim Dinç, Kumru Çılgın, Esra Turgut), Sayı 1, 11-14, Haziran. ISBN: 978-625-400-808-5.

7. Çörek Öztaş, Ç. (2020). Kentlerin Akıllanmasına Pandemi Etkisi, Star Gazetesi. https://www.star.com.tr/acik-gorus/kentlerin-akillanmasina-pandemi-etkisi-haber-1525986/, (1.04.2020).

8. Değerliyurt, M., Çabuk, S. N. (2015). Coğrafyayı Coğrafi Bilgi Sistemleri ile Tanımlamak. Doğu Coğrafya Dergisi, 20 (33), 37-48.

9. DSÖ (2020a). https://www.who.int/emergencies/diseases/novel-coronavirus-2019/events-as-theyhappen, (25.05.2020).

10. DSÖ (2020b). Coronavirus Hastalı̆̆ 2019 (COVID-19) Durum Raporu-94. https://www.who.int/docs/default-source/coronaviruse/situation-reports/20200423-sitrep-94-covid19.pdf?sfvrsn=b8304bf0_4, (27.04.2020).

11. DSÖ (2020c). Koronavirüs Hastalığı (COVID-19) Kontrol Paneli. https://covid19.who.int/, (3.6.2020).

12. DSÖ (2020d). Koronavirus hastalığ 2019 (COVID-19) durum raporu-51. https://www.who.int/docs/default-source/coronaviruse/situation-reports/20200311-sitrep-51-covid19.pdf?sfvrsn=1ba62e57_10, (29.03.2020).

13. DSÖ (2020e). Koronavirus Hastalığı 2019 (COVID-19) Durum Raporu-89. https://www.who.int/docs/default-source/coronaviruse/situation-reports/20200418-sitrep-89-covid19.pdf?sfvrsn=3643dd38_2, (20.04.2020).

14. Erdem, M. (2020). Pandemi, Tasarım ve Mimariye Yeni Kriterler Getirecek. https://www.aa.com.tr/tr/turkiye/pandemi-tasarim-ve-mimariye-yeni-kriterler-getirecek-/1871700. (Kübra Kara, Mücahit Türetken), (01.07.2020).

15. Erez, H. (2003). Kültür-Mekân Etkileşimine Bağlı Şehirsel Doku Farklılaşmaları: KumkapıSüleymaniye Örneği, Yüksek Lisans Tezi (yayınlanmamış), İstanbul Teknik Üniversitesi Fen Bilimleri Enstitüsü, 154s.

16. Gül, F. (2013). İnsan-Doğa İlişkisi Bağlamında Çevre Sorunları ve Felsefe. Pamukkale Üniversitesi Sosyal Bilimler Enstitüsü Dergisi, (14), 17-21.

17. Honey-Roses, J., Anguelovski, I., Bohigas, J., Chireh, V., Daher, C., Konijnendijk, C., ... Nieuwenhuijsen, M. (2020). The Impact of COVID-19 on Public Space: a Review of the Emerging Questions. OSF Preprints. https://doi.org/10.31219/osf.io/rf7xa.

18. Kor, A. (2011). Koruma Alanı Yakınındaki Hızlı Kentleşmenin Peyzaj Ekolojisi Yaklaşımı ile İrdelenmesi. Doktora tezi, İTÜ Fen Bilimleri Enstitüsü, Peyzaj Mimarlığı Anabilim Dalı, İstanbul, 156 s.

19. Koyuncu, M. (2008). Salgın Hastalıkların Önlenmesinde Kaynak Atama Probleminin İncelenmesi. Doktora tezi, Çukurova Üniversitesi Fen Bilimleri Enstitüsü, Endüstri Mühendisliği Anabilim Dalı, Adana, 152s. 
20. Last, J. M. (2001). A Dictionary of Epidemiology. 4th Edition. Oxford University Press, New York.

21. Lee, V. J., Ho M., Kai C. W., Aguilera, X., Heymann D., Wilder-Smith, A. (2020). Epidemic Preparedness in Urban Settings: New Challenges and Opportunities, The Lancet Infectious Diseases., 20(5), 527-529, doi:10.1016/S1473-3099(20)30249-8.

22. Mekânsal Planlar Yapım Yönetmeliği (2014). Resmi Gazete, 14.06.2014 (29030), EK-2 Kentsel, Sosyal ve Teknik Altyap1, https://www.resmigazete.gov.tr/eskiler/2014/06/20140614-2.htm, (20.06. 2020).

23. NASA (2020). Reductions in Pollution Associated with Decreased Fossil Fuel Use Resulting from COVID-19 Mitigation, https://svs.gsfc.nasa.gov/4810, (4.6.2020).

24. Özden, K., Özmat, M. (2014). Salgın ve Kent: 1347 Veba Salgınının Avrupa'da Sosyal, Politik ve Ekonomik Sonuçları. Idealkent, 12, 60-87.

25. Özgüner, H. (2009). Doğal Peyzajın İnsanların Psikolojik ve Fiziksel Sağlı̆̆ı Üzerine Etkileri. Turkish Journal of Forestry, A(2), 97-107.

26. PMO (2020). Salgınlarla Mücadelede Peyzaj Mimarlarının Rolü Üzerine. Peyzaj Mimarları Odası, 13. Dönem Yönetim Kurulu. http://www.tmmob.org.tr/icerik/peyzajmo-salginlarla-mucadelede-peyzajmimarlarinin-rolu-uzerine, (05.06.2020).

27. Reyes, R., Ahn, R., Thurber, K., Burke, T. F. (2013). Urbanization and Infectious Diseases: General Principles, Historical Perspectives, and Contemporary Challenges. I.W. Fong (Ed.), Challenges in Infectious Diseases, Springer, New York, pp. 123-146.

28. Russo, A., Cirella, G. T. (2018). Modern Compact Cities: How Much Greenery Do We Need? International Journal of Environmental Research and Public Health, 15(10), 2180-2195. https://doi.org/10.3390/ijerph15102180.

29. Samuelsson, K., Barthel, S., Colding, J., Macassa, G., Giusti, M. (2020). Urban Nature As A Source of Resilience During Social Distancing Amidst the Coronavirus Pandemic. OSF Preprints. https://doi.org/10.31219/osf.io/3wx5a.

30. Şeker, M., Özer, A., Tosun, Z., Korkut, C. Doğrul, M. (2020). Covid-19 Pandemi Değerlendirme Raporu. Ankara: Türkiye Bilimler Akademisi. 17 Nisan 2020, Ankara. http://www.tuba.gov.tr/files/yayinlar/raporlar/Covid-19\%20Raporu-revize.pdf, (02.06.2020).

31. UNDP (2020). COVID-19 Pandemisi. https://www.tr.undp.org/content/turkey/tr/home/coronavirus.html, (20.05.2020).

32. UNESCO (2020). COVID-19 Educational Disruption and Response. https://en.unesco.org/covid19/educationresponse, (20.05.2020).

33. URL-1 (2020). https://www.iklimhaber.org/hastaliklarin-ekolojisi-insan-doga-etkilesimleri/, Hastalıkların Ekolojisi: İnsan - Doğa Etkileşimleri, (10.04.2020).

34. URL-2 (2020). We did it to ourselves': scientist says intrusion into nature led to pandemic. https://www.theguardian.com/world/2020/apr/25/ourselves-scientist-says-human-intrusion-naturepandemic-aoe\#maincontent, (30.04.2020).

35. URL-3 (2020). TMMOB Peyzaj Mimarları Odası İzmir Şubesi Basın Açıklaması: "Bu pandemi bir kentleşme sorunu olarak da değerlendirilmeli". https://www.izgazete.net/genel/bu-pandemi-birkentlesme-sorunu-olarak-da-degerlendirilmeli-h45506.html, (15.04.2020).

36. URL-4 (2020). A Deer Walks Through an Underpass in Search For Food - A Common Site in Nara, Japan. Photo: AP, https://www.scmp.com/news/world/article/3077518/coronavirus-wild-animals-takeback-worlds-empty-city-streets-people-stay, (10.05.2020).

37. URL-5 (2020). A Puma on the Streets of Chile's Capital Santiago on March 24. Photo: AFP. https:/www.scmp.com/news/world/article/3077518/coronavirus-wild-animals-take-back-worldsempty-city-streets-people-stay, (10.05.2020).

38. URL-6 (2020). Residents of Istanbul Say Dolphins are Coming Further up the Bosphorus than Usual AFP. https://www.bbc.com/news/world-52459487, (10.05.2020).

39. URL-7 (2020). A Woman Stops to Watch the Fallow Deer From Dagnam Park as They Rest and Graze on the Grass Outside Homes on a Housing Estate in Harold Hill, Near Romford on April 2, 2020 in Romford, England. https://globalnews.ca/news/6851572/earth-day-2020-coronavirus/, (10.05.2020).

40. URL-8 (2020). These Goats Normally Live on the Rocky Great Orme Headland in Wales but are Occasional Visitors to the Nearby Seaside Town of Llandudno. Photograph: Christopher Furlong/Getty Images https:/www.theguardian.com/world/gallery/2020/apr/22/animals-roaming-streets-coronaviruslockdown-photos, (10.05.2020).

41. URL-9 (2020). Macaques Fight in the Streets of Lopburi, Thailand on March 11, 2020. Sasaluk Rattanachai/Facebook https://globalnews.ca/news/6851572/earth-day-2020-coronavirus/, (10.05.2020)

42. URL-10 (2020). Sika Deer Cross a Road in Nara, Japan. The Animals Have Been Wandering Through City Streets and Subway Stations. Photograph: Tomohiro Ohsumi/Getty Images, 
https://www.theguardian.com/world/2020/mar/22/animals-cities-coronavirus-lockdowns-deerraccoons, (10.05.2020).

43. URL-11 (2020). Wild Boar in Haifa, Israel are Enjoying Food Left in Residents' Rubbish Bins EPA, https://www.bbc.com/news/world-52459487, (10.05.2020).

44. URL-12 (2020). Domino Park Introduces Social Distancing Circles to Adapt to the COVID-19 Crisis. Written by Christele Harrouk, Photographed by Marcella Winograd. https://www.archdaily.com/940244/domino-park-introduces-social-distancing-circles-to-adapt-to-thecovid-19-crisis, (04.06.2020).

45. URL-13 (2020). Seyhan'da Parklara Sosyal Mesafeli Bank Yerleştiriliyor, https://www.cnnturk.com/yerel-haberler/adana/merkez/seyhanda-parklara-sosyal-mesafeli-bankyerlestiriliyor-1530398, (1.07.2020).

46. URL-14 (2020). The World After the Pandemic: Covid19 Free Dining Spaces in Amsterdam, Editor Wander Lust, https://tophotel.news/live_blog/the-world-after-the-pandemic-covid19-free-diningspaces-in-amsterdam/, (1.07.2020).

47. URL-15 (2020). İzmir'de Çemberli Sosyal Mesafe Önlemi, https://www.haberturk.com/izmir-desosyal-mesafe-cemberi-2687918, (1.07.2020).

48. URL-16 (2020). New Social Distancing Markings Have Been Installed on a Number of Walkways Around Dundalk. Mar 27, 2020 |Headline, Local News, https://www.talkofthetown.ie/new-socialdistancing-markings-installed-on-local-walkways/, (1.07.2020).

49. Uslu, A. (2011). Çevre Nedir? Ed. M. E. Yazgan, Peyzaj, Çevre ve Tarım, T.C. Anadolu Üniversitesi Yayın1, No: 2282.

50. WWF (2020). Doğanın Yok Oluşu ve Pandemilerin Yükselişi İnsanların ve Gezegenin Sağlı̆̆ını Korumak.https://d2hawiim0tjbd8.cloudfront.net/downloads/doann_yok_oluu_ve_pandemilerin_yukse lii_25_04_20.pdf?9920/Doganin-Yok-Olusu-ve-Pandemilerin-Yukselisi, (3.06.2020).

51. Yanık, T., Günyol, A. (2020). Hayat Eve Sığar Uygulaması, https://www.aa.com.tr/tr/turkiye/hayateve-sigar-uygulamasi-5-milyonun-uzerinde-indirildi/1831032, (30.06.2020).

52. Yiğit, İ., Gümüşçü, O. (2016). Manisa ve Çevresinde Salgın Hastalıkların İskâna Etkisi (XVI-XX. yy.), TÜCAUM Uluslararası Coğrafya Sempozyumu, 13-14 Ekim, 379-391. 